\title{
Profiles of opportunistic infections in people living with HIV followed at the Military Hospital of Kinshasa Reference (Camp Kokolo), DRC
}

\author{
NE Kamangu*, NH Situakibanza, LG Mvumbi, IL Kakudj, TD Tshienda, TG MESIA \\ From 17th International Symposium on HIV and Emerging Infectious Diseases (ISHEID) \\ Marseille, France. 23-25 May 2012
}

\section{Introduction}

In the Democratic Republic of Congo (DRC), Opportunistic Infections (OI) are still a major problem in the care of People Living with HIV (PLHIV). Through the military medical program, few data are available regarding the treatment and prevention of OI. Because of their high mobility and the environment in which they live, the security forces may be considered a population at risk. This study aims to determine the profile of opportunistic infections encountered in PLHIV supported the Military Hospital of Kinshasa Reference (Camp Kokolo / DRC).

\section{Methodology}

This study was conducted at the Military Hospital of Kinshasa Reference (HMRK). It is a literature review that focused on issues of HIV adult patients 18 years followed in the course of January $1^{\text {st }}$ to December $31^{\text {st }} 2010$. The elements of interest were: age, sex, infections diagnosed. Records that did not contain all of these data were not included.

\section{Results}

Tuberculosis (43.2\%), candidacies (oral (16.7\%), vaginal (2.3\%) and esophagus $(1.5 \%)$ ) prurigo (15.9\%), pneumonia $(11,4 \%)$, malaria $(10.6 \%)$, herpes zoster $(9.8 \%)$, isosporiasis (5.3\%), condyloma (3.8\%) and salmonella (3.8\%) infections were found in patients with HIV attending HMRK.

\section{Conclusion and recommendations}

Tuberculosis, oral candidacies, prurigo, pneumonia and malaria are the opportunistic infections found in these

* Correspondence: erick.kamangu@unikin.ac.cd

Université de Kinshasa, Kinshasa, Congo patients. We believe it is necessary to systematize the search for co-association of tuberculosis in any PLHIV.

Published: 25 May 2012

doi:10.1186/1742-4690-9-S1-P146

Cite this article as: Kamangu et al:: Profiles of opportunistic infections in people living with HIV followed at the Military Hospital of Kinshasa Reference (Camp Kokolo), DRC. Retrovirology 2012 9(Suppl 1):P146.
Submit your next manuscript to BioMed Central and take full advantage of:

- Convenient online submission

- Thorough peer review

- No space constraints or color figure charges

- Immediate publication on acceptance

- Inclusion in PubMed, CAS, Scopus and Google Scholar

- Research which is freely available for redistribution
() Biomed Central 